\title{
Herbage intake rates and grazing behaviour of sheep and goats grazing grass or white clover
}

\author{
PD Penning 1, RJ Orr ${ }^{1}$, AJ Parsons ${ }^{1}$, A Harvey ${ }^{1}$, JA Newman 2 \\ I/GER, North Wyke, Okehampton, Devon EX20 2SB, UK ; '2Dept of Zoology, Southern IIIinois University, \\ Carbondale, IL 62901-6501, USA
}

Sheep with a low intake potential (nonpregnant, non-lactating) grazing monocultures of white clover have higher intake rates and lower grazing times than those grazing grass (Penning et al, 1991, Appl Anim Beh Sci, 31, 237-250). To examine whether goats show similar behaviour, 24 Scottish Halfbred ewes $(92 \pm 1.39 \mathrm{~kg})$ and 24 British Saanen does $(64 \pm 1.32 \mathrm{~kg})$ grazed, at $6 \mathrm{~cm}$ sward surface height, either monocultures of perennial ryegrass (Lolium perenne $L$. cv Parcour) or white clover (Trifolium repens $L$. cv Kent Wild White) in 12 groups containing 4 animals. The experiment had a 2 (sheep or goats) $\times 2$ (grass or clover) factorial design with treatments replicated on three occasions. On each occasion different plots and animals were used and herbage intake rates were measured during the main evening meal, starting at 18:00 $\mathrm{h}$ approximately. Animals had been on their respective plots for at least one week before intake rate was measured over $1 \mathrm{~h}$ using a weighing technique (Penning and Hooper, 1985, Grass For Sci, 40,79-84) and by use of an automatic system of recording grazing behaviour (Penning et al, 1984, Grass For Sci, $39,345-351$ ). Subsequently, recordings of grazing behaviour over $24 \mathrm{~h}$ were made on two further occasions.

Sheep and goats had similar dental incisor arcade widths $(39.3 \vee 37.2 \mathrm{~mm} \pm 0.80)$. Prehension rates, mastication rates and bite mass were not significantly affected by animal or herbage species. Intake rates were higher $(P<0.05)$ for sheep than goats and tended to be higher on clover than grass, but there were no significant differences in intake rate when expressed per $\mathrm{kg} L W 0.75$. The goats on both herbage species and the sheep on grass grazed very little during the hours of darkness (<20 min), unlike the sheep grazing clover (74 min). Total daily DM intakes of clover and grass were similar for sheep (both $2.52 \mathrm{~kg}$ $\mathrm{DM} /$ day) and goats ( 1.33 and $1.46 \mathrm{~kg} \mathrm{DM} /$ day), and these differences between animal species were significant in absolute terms $(P<0.001)$ and per $\mathrm{kg} \mathrm{LW} 0.75(P<0.01)$. Both animal species regulated daily intake by changing grazing time. Thus, short term measurements of intake rates, alone, were not correlated with intake. To predict nutrient supply to grazing animals, an understanding of factors controlling grazing time is essential.

\begin{tabular}{lcccc}
\hline & \multicolumn{2}{c}{ Sheep } & \multicolumn{2}{c}{ Goats } \\
& Grass & Clover & Grass & Clover \\
\hline Prehension (bites/min) & 56.5 & 67.3 & 58.7 & 62.9 \\
Mastication (bites/min) & 96.9 & 87.8 & 91.1 & 89.2 \\
Bite mass (mg DM/bite) & 84.1 & 78.1 & 64.0 & 71.2 \\
Intake rate (g DM/min) & 4.3 & 5.2 & 3.5 & 4.0 \\
Times spent : & & & & \\
$\quad$ Grazing (min/24h) & 587 & 483 & 417 & 328 \\
$\quad$ Ruminating (min/24h) & 415 & 156 & 222 & 44 \\
Idling (min/24h) & 438 & 801 & 801 & 1068 \\
\hline
\end{tabular}

